\title{
The energy industry and environmental challenges
}

\author{
P. S. Maharaj \& K. Ramnath \\ Petroleum Company of Trinidad and Tobago Limited, \\ Trinidad and Tobago
}

\begin{abstract}
Trinidad and Tobago is considered a small island republic with continentally sized industries such as petroleum refining, methanol and natural gas processing. As a result of the increasing demand for petrochemical products on the worldwide market, the augmented through-put per plant is generating escalating volumes of waste. Although there has been some progress on the definition for hazardous waste generated from local industries, with the development of draft hazardous Waste Management Rules, many issues of concern exist in this interim period. While the country is aimed at supporting other local health, safety and environmental legislation, the management of Hazardous Waste has become an inconvenient oversight in the successful attempts at compliance.

At present, there are no major deterrents on pollution prevention with these cost intensive waste streams and environmental degradation has been growing exponentially. This paper examines the environmental feasibility of hazardous waste treatment and disposal for the largest energy company in the Caribbean an oil refinery, given the throughput, demand for products, amount and type of waste generated, legislative framework and local environment for disposal.

Keywords: petroleum, hazardous, legislation.
\end{abstract}

\section{Introduction}

Trinidad and Tobago operates as a large scale energy industry within the Caribbean basin (see location map, Figure 1), generating correspondingly sized waste streams. These hazardous industry wastes threaten not only the sustainability of the natural environment, but also the well being and existence of 
local inhabitants of the island. While the local legislative framework is operational, the tools needed to enforce these aims and guidelines are absent.

The lack of availability of commercial hazardous waste treatment facilities is not only a significant environmental issue, but also an essential economic factor for nations with rapidly growing industries. Without the means to treat and dispose of hazardous waste, it is not possible to enforce environmental legislation. The treatment and disposal methods and equipment must therefore be specified to ensure compliance. Implementing measures to minimize environmental and occupational safety risks to the operator and receiving environment can guarantee the sustainable existence of industry and man. Hazardous waste incinerators and landfill disposal units ensure the success of the relevant emission standards for industry.

Such facilities can be located in the La Brea area of South Trinidad, in close proximity to an existing operational waste treatment site for non-hazardous oilfield waste, as this area is well suited for an industrial furnace and a land fill (given the soil type). The siting and operations of these facilities will enable industry to have the tools by which to enable legislative compliance with waste emission standards.

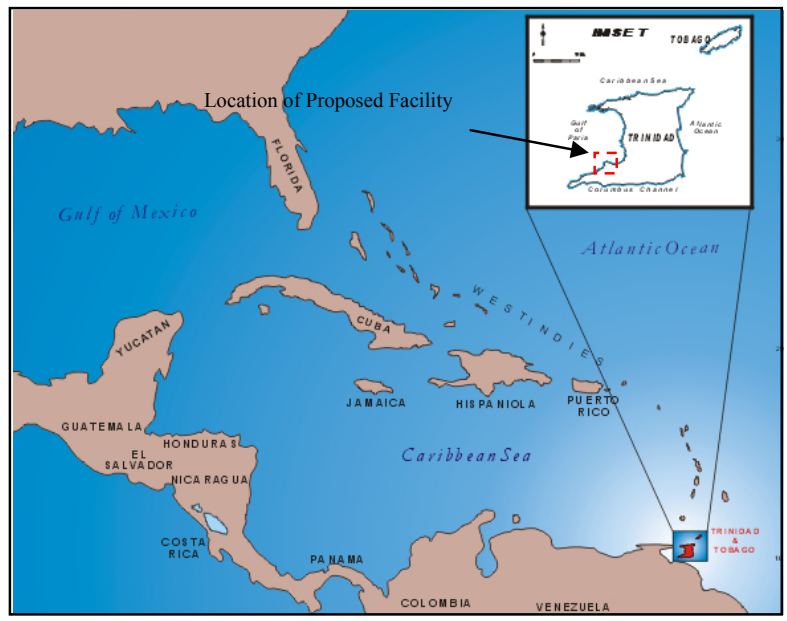

Figure 1: $\quad$ Location map of Trinidad and Tobago.

\section{Legislation governing hazardous waste management}

Chemical waste exhibiting the properties of ignaitbility, reactivity or toxicity are considered hazardous, and must be managed accordingly. Trinidad and Tobago relies on the legislative framework outlined by the Environmental Management Act (2000) [4] for guidance on waste management and the Hazardous Waste Management Rules of Trinidad and Tobago were drafted in response to this requirement. This piece of legislation provides for the recognition and identification of hazardous waste generators, where they will be obligated to 
register as polluters, and in this activity of 'recognition', they will then be responsible for ensuring the appropriate storage, transport and disposal methods for all wastes of an adverse nature.

This piece of draft legislation is founded on basic principles including those of:

- Duty of Care - the individual or organization that generates a waste incurs a duty of care that is owed to society.

- Polluter pays principle - This principle holds that the person or organization causing pollution is liable for any costs involved in cleaning it up or rehabilitating its effects.

The local draft Standards applicable to generators of hazardous waste must effectively outline the responsibility of the Generators who have registered with the Environmental Management Authority. These responsibilities include, but are not limited to:

- Adequate and accurate labels for any containers used for the storage, transport, or disposal.

- Supplying relevant information for transport, treatment, storage, or disposal.

- Utilization of a manifest system with permitting for transport, treatment, storage, or disposal.

- Ensuring that efforts are undertaken to reduce the volume and toxicity of waste generated.

Some challenges associated with the existing framework include:

- It is still within a draft format, within a country with live hazardous waste pollution issues.

- The framework assumes the functionality of first world waste treatment and disposal facilities - none of which are currently available for implementation. If local operators are being legislated to register to pollute certain volumes of waste, then there must be an end point for pollution - i.e. they must also be legislated to utilize a facility that will guarantee successful disposal.

While the 'duty of care' and 'polluter pays' principles are useful tools in establishing responsibility for avoiding careless and reckless environmental endangerment - it is a first world principle. To effectively ensure that first world industries operating in non first world societies abide by these principles - the corresponding facilities must be provided. This type of legislation must teach and guide companies on the efficiency of sound environmental practice - rather than encourage small quantity generators to be put out of business because of the inability to manage their wastes.

The National Oil and Gas Company of Trinidad and Tobago supports the local economy. While conscientious operations are desired, the tools to ensure successful management of waste are needed. These tools include facilities that ensure the cradle to grave for hazardous industrial wastes. 


\section{Hazardous waste in the upstream and downstream petroleum industry}

The following table details the types of hazardous wastes generated from both the oil industry that requires specialized disposal:

Table 1: $\quad$ Hazardous wastes from the oil industry [2].

\begin{tabular}{|l|l|l|}
\hline Waste Type & Current treatment method & $\begin{array}{l}\text { Annual } \\
\text { Volume }\end{array}$ \\
\hline $\begin{array}{l}\text { Gasoline Storage Tank } \\
\text { Sludge }\end{array}$ & $\begin{array}{l}\text { Treatment and disposal contracted to US } \\
\text { based companies. }\end{array}$ & 150 barrels \\
\hline $\begin{array}{l}\text { Spent catalyst from the } \\
\text { refinery Hydrogen and } \\
\text { Hydrotreater plants }\end{array}$ & $\begin{array}{l}\text { When the cobalt molybdenum catalysts } \\
\text { can no longer be regenerated, they are } \\
\text { treated for the heavy metals, and disposed } \\
\text { abroad. }\end{array}$ & $\begin{array}{l}114 \text { tons of } \\
\text { Catalyst }\end{array}$ \\
\hline $\begin{array}{l}\text { Spent Mercury from } \\
\text { Laboratory Testing }\end{array}$ & $\begin{array}{l}\text { Currently no disposal method. Aqueous } \\
\text { mercury is being stockpiled at until a } \\
\text { disposal method is provided }\end{array}$ & 0.75 litres \\
\hline
\end{tabular}

It should be noted that similar hazardous waste streams are found in other local industries.

\subsection{Impacts of hazardous waste disposal}

Improperly treated and disposed wastes such as those from the petrochemical industry contain high levels of heavy metals, phosphates and sulfur from additive chemicals and will have the following impacts:

- Ground and surface water contamination from leaks, spills and accidents leading to temporary or permanent contamination of sites

- Air pollution (from improper combustion, smog formation, etc.)

- Destruction of wildlife habitat, natural areas, wetlands

- Loss of any unique site features (e.g. archaeological)

- Contamination of nearby crops, fisheries

- Others: Traffic congestion, odours and noise

Heavy metals contained in oils as well as oil treating additives such as catalysts include metals such as cadmium, copper, nickel, lead, and zinc, which can be released into the atmosphere, and aquatic environments. These metals can become serious environmental and health concerns even when widely dispersed.

\section{The way forward}

Although current operations seek to treat and dispose of all waste streams, optimal levels of waste management have not been reached. The local oil industry requires treatment, storage and disposal facilities for waste streams that cannot be reduced at source or recycled in the processing stage. 
Many small scale contractors are employed to collect, treat and dispose of hazardous wastes, but very few are equipped with facilities and land space for handling large quantities of hazardous waste streams. Again, with the absence of enforceable legislation on hazardous waste disposal, these contractors are utilizing unapproved methods, dumpsites, and facilities. Many companies proactively aim at sustainable development tempered with environmental protection, but the cradle-to-grave approach (with process inputs, contractor operations and waste streams) is not vigilantly pursued. In recognition of the environmental impacts that can be caused with the improper disposal of hazardous waste, with numerous small-scale contractors disposing waste unacceptably (worse case scenario), countless environmental liability sites are created and persist in the environment. These in turn have to be re-remediated. With an all-encompassing facility, the use of numerous contractors is significantly reduced, as with the number of liability sites for future re-disposal.

Only until industry can engage with managing with the end in mind, can production cycles culminate in environmentally sound outputs and bi-products. Operations (including inputs/raw materials), infrastructural works and plant designs must be reviewed to ensure that the bi products/emissions and final wastes are as environmentally secure as possible. Efficient product and the corresponding waste management techniques must therefore be implemented from the initial project stage, in order to achieve 'safe' operating conditions, as well as shut down conditions for the industry.

Management via Incineration treatment and landfill disposal can be utilized for this hazardous industry waste.

These methods (detailed in further sections) will ensure a guaranteed compliant treatment and disposal method for large and small scale producers.

\subsection{Incineration}

Treatment of wastes by incineration has had proven effectiveness in waste reduction. Incineration can destroy all organic waste toxicity and the volumes can be reduced by up to $90 \%$. The main benefit in this process is that less land fill space is needed, and the need for new landfills is reduced.

It is internationally accepted and recommended that fluidized bed incinerators are the best available technology for the combustion of hazardous waste. Its high contact surface waste/air, high heat transfer, turbulence and mixing properties offer the best combustion efficiency.

This system is successfully used for waste either in the form of liquid waste, waste containing high molten salt, sludge containing high water content and solids. Ash discharged from the incinerator is cooled and collected for disposal. Ash remaining after incineration may require treatment (solidification/stabilization to reduce metal leachability) prior to disposal. It is noted that the incinerator does not bring heavy metals to a reduced state (chemically). The overall aim of this combustion system is to reduce the hazardous waste by burning off the hydrocarbons (and other organic matter), and disposing of the remaining metals that have now been reduced to fly ash, and solid residue. 
The incinerator for this type industry will handle only the following wastes:

- The historically accumulated Leaded Tank Sludge - The incinerator will effectively burn off the hydrocarbon contaminants, leaving behind lead in the ash and solids to be solidified and encapsulated for land filling.

- Spent Refinery Catalyst - This will become a routine waste stream for the incinerator, as it is a constant input for refinery operations.

- The accumulated mercury.

\subsection{Treatment}

The most unique application of cement in waste management is for solidification/stabilization $(\mathrm{S} / \mathrm{S})$ treatment of waste. $\mathrm{S} / \mathrm{S}$ treatment of waste involves mixing Portland cement into contaminated media or waste to immobilize contaminants within the treated material. Alternatively, another stabilization method using sulfur cement is also available for hazardous wastes. The sulfur cement is easily melted at $248^{\circ} \mathrm{F}\left(120^{\circ} \mathrm{C}\right)$ to form a low viscosity liquid, which can be adapted for use in a number of different waste processes. The process simultaneously heats the waste and binder with several additives to form a homogenous mixture. Additives are used to enhance waste form durability and to immobilize soluble toxic metals contained in the waste. The compressive and tensile strength of sulfur concrete twice those of comparable Portland concrete that can be achieved using this process. (Full strength is attained in several hours rather than weeks).

Unlike the hydraulic cement processes that rely on chemical reactions for setting and solidifying, the sulfur polymer cement encapsulation process does not require a chemical reaction. Rather, it is compatible with a wide range of waste types and can accommodate higher waste loadings (more waste per drum than conventional systems). Further, as much as 2.5 times more incinerator fly ash can be solidified in sulfur polymer cement than in hydraulic cement. These improvements in waste loading reduce the number of waste drums to be processed for storage, transport, and disposal, thus reducing overall costs. Sulfur polymer cement encapsulation can be used to improve waste treatment at chemical and manufacturing facilities that generate hazardous wastes, environmental restoration sites, municipal solid waste incinerators, and waste-toenergy plants. Sulfur polymer cement waste forms also demonstrated excellent durability and performance under anticipated storage, transport, and disposal conditions.

\subsection{Landfilling}

A hazardous waste landfill must be a carefully designed structure built into or on top of the ground in which the content is isolated from the surrounding environment (groundwater, air, rain). This isolation is accomplished with a bottom liner and top cover. The purpose of a landfill is to bury the waste (in its treated form) in such a way that it will be completely isolated from groundwater, dry and will not be in contact with air. Under these conditions, the waste is not to decompose or experience physical-chemical changes. The physical environment 
must support zero emission principle of the landfill, and must therefore be located in soils of restricted internal drainage (see Figure 2).

The landfill must be constructed with the appropriate leachate, liner systems and cells. These spaces are designed to accommodate the solidified cores of hazardous waste (solidified as cylindrical cores, or rectangular slabs), where after, the solids are placed, the hole is sealed (by high density cement, or similar material used in the lining). The design of this facility must accommodate storm water (rain water), and so inter-drainage must be facilitated. The sealed cores with the hazardous waste must not be bored, but the empty holes must be drained. Upon filling a holding space, the drainage is usually closed off. The drained liquids from this facility are usually collected, sampled and treated (if necessary, although the storm water should be free of any hazardous waste contaminants), prior to discharge into public watercourses.

\section{Recommendations}

The legislative framework defined in Trinidad and Tobago to manage the negative impacts from improper disposal of hazardous waste is incapable of managing environmental pollution. It lacks the enforcement component to truly make this policy system successful. Additionally, even with the sufficient amount of enforcement, the technology for hazardous waste disposal is not affordable by all generators, or is currently available locally.

The draft hazardous waste management legislative framework in Trinidad and Tobago must take into consideration the current waste situation. Contracted (and other) local waste services are not conformant with the cradle-to-grave approach for waste disposal, and if sustainable growth and existence are anticipated with the energy sector, these practices must immediately be discontinued. While the existing framework of the Environmental Management Act is not organized, first world principles cannot be adopted.

Organizations will not adhere to strict disposal rules for waste streams for one simple reason - the high cost of abiding. The recommendations therefore to the existing legal framework, are to stipulate the hazardous waste emission guidelines, applicable quantities for generators, and permitting requirements with specific infrastructure for treatment. It is recommended that the equipment for hazardous waste disposal are selected and even subsidized and run by the government for use by industry. The single oil refinery in Trinidad alone produces almost 200 tons of hazardous waste per year. If the environmentally conscious incineration and landfills are provided or are available locally, then the size and capacity can be expanded to absorb the waste volumes of other international generators. Many international legislative frameworks stipulate steep penalties for non-compliant waste generators (in excess of stated emission limits). Such a tool in this embryonic stage of environmental legislation can serve to shut industries down, since the cost of compliance will be exorbitant. If technology standards were included as part of the required emission standards, hazardous waste generators would inevitably meet and exceed the requirements. These tools guarantee the success of the legislative framework. 
This type of location for hazardous waste treatment and disposal can function in Trinidad. The Brighton or Vessigny areas of South Trinidad (not residential nor commercial) have seasonal watercourses, and the wind direction of the island (North-East Trade Winds) will appropriately manage the dispersion of the plume (see Figures 1 and 2 for the location of the island and the proposed facility).

SOUTH TRINIDAD SOIL MAP - LABIDCO
SITE
Legend
Soil Groups
$\square$ Deep cultivated beach sand with free interna drainage.
$\square$ Deep hydromorphic soils with restricted internal drainage.
$\square$ Deep alluvial scils with free internal drainage.
Deep alluvial scils with restricted internal dranage
$\square$ Terrace sol s with free internal dranage.
$\square$ Terrace soi s with restricted internal dranage.
$\square$ Soils of the intermedate uplands with free internal drainage
Soils of the intermedate uplands with restricted internal drainage.
High upland scils with free internal drainage
High upland scils with restricted internal drainage
Horth Western District

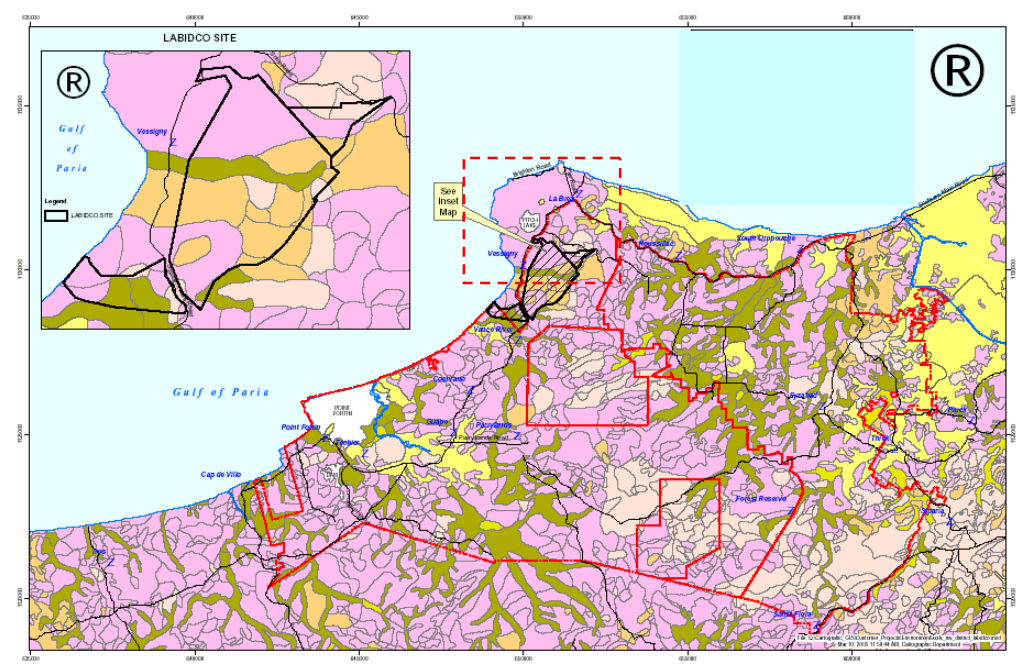

Figure 2: $\quad$ Soil map of South-Western Trinidad [6].

The geology of this area includes soils of the intermediate uplands with restricted internal drainage. This is appropriate for a facility, where downward leaching is undesirable and must be prevented. This soil type can enable some cost savings where artificial linings can be minimized. The entire area in the vicinity of Brighton Road is characteristic of restricted drainage, which implies that the probability coastal pollution from contaminant leaching is minimal. The area is also not within an inundated flat or flood plain, which implies that the encapsulation area will be flood free. The sulphur cement is reaction resistant from chemicals - which imply an indefinite safe disposal of these chemicals. The ground water is therefore adequately protected from any chemical 
degradation of the cores within the facility, as well as these wastes being improperly disposed of elsewhere. Additionally, within the context of the Certificate of Environmental Clearance Application Requirements of Trinidad and Tobago (for new facilities), this type of facility is not in hindrance to any existing watercourses - again, not affecting the domestic, recreational or aesthetic value of water in the proposed area.

This facility will reduce the amount of liability sites in Trinidad and Tobago, while also reducing the number of waste management contractors who dispose of hazardous wastes improperly. It will eliminate the concept of 'out of site - out of mind' by introducing effective waste reduction and disposal methods and facilities.

If this waste management methodology is supported and embedded into the existing laws, where generators are required to dispose of their identified hazardous wastes by incineration, then there is a continuous need and market for this facility. With government subsidizing (and operating) the facility within the framework of environmental legislation, there will be a forced compliance with emission standards. The potential exists to utilize the facility commercially, (beyond the requirements of the national oil and gas company), given the large number of industrial processing companies locally and even regionally.

The operability of the National Oil and Gas Company directly affects the economy of the country, and such a facility to support long-term viability of the industry within its operating environment, will achieve an equitable trade off. Thus, the provision of technology standards to ensure the graveyard of wastes, also ensures successful enforcement of legislation and the sustainable industrial growth and survival.

\section{References}

[1] 2003, Drafting Instructions for Waste Management Rules, Draft Waste Management Rules for Trinidad and Tobago. Port-of-Spain Trinidad and Tobago: Government Printer.

[2] 2004. Petroleum Company of Trinidad and Tobago Limited, Refining and Marketing Company Division Engineering Design Office, 2004 Product Statistics file for Waste Disposal from Refining Operations. Used with permission 2006.

[3] Bagchi, A. 1994. Design, Construction, and Monitoring of Landfills. New York: John Wiley \& Sons Inc.

[4] Environmental Management Act, 2000. Port-of-Spain Trinidad and Tobago: Government Printer.

[5] Maughan, James T. 1993. Ecological Assessment of Hazardous Waste Sites. New York: Van Nostrand Reinhold.

[6] Soil Map of South-Western Trinidad - (Used by Permission, Petrotrin Geological Drawing Archive 2001-TOPO 1936) 